\title{
Learning framework for the development of key skills in the hospitality industry
}

\author{
Gisela Domínguez \\ Lecturer at School of Tourism and Hospitality Management Sant Ignasi, Universitat Ramon Llull, Spain \\ Gisela.dominguez@htsi.url.edu
}

\section{Albert Fornells Herrera}

professor at School of Tourism and Hospitality Management Sant Ignasi, Universitat Ramon Llull, Spain

Received: 20/10/2020 Revised: 9/11/2020 Accepted: 1/12/2020 DOI: https://doi.org/10.31559/IJHTS2020.1.2.6

\begin{abstract}
:
The hospitality sector is one of the most competitive industries and it is one of the leading engines of the world economy. The current crisis in the sector due to the COVID-19 makes organizations to consider more than ever the unique and the alignment of their services for becoming different from their competitors. In this sense, the hospitality skills have been identified as one of the crucial elements in the strategy by the companies because of the wide and diverse offer of tourism services and, at the same time, the new customer expectations which are pushing the organizations to create customized, unique and memorable experiences. Thus, this change of paradigm leads to a constant reflection on the quality that services should offer in line with customer expectations. The aim of this research is twofold. On the one hand, the article identifies service orientation, empathy and teamwork as key competences in the development of the hospitality skills. On the other hand, the paper presents a learning framework of those skills within the University studies. This framework proposes an incremental learning process organized in three phases -Discover, Reflection and Experience- through the period of the academic program. First, the identification of their hospitality profile based on the three skills is done through a discovered process. Next, students reflect about the contents and best practices related to strategical and operational aspects linked to the sector. Finally, students experience all the previous concepts through an internship. One of the main benefits of this learning framework is that allows academic supervisors to define goals and monitoring the achievement of these competences of the students along the different academic years.
\end{abstract}

Keywords: Digital Transformation; Tourism \& Hospitality; EHEA; Artificial Intelligence and Software Engineering

\section{Introduction}

The tourism and hospitality sector has become a reference point for the world economy and the development of its activity is influenced by the relationships between people and cultures. The competitiveness is other of the main characteristics of this industry due to the diversity of companies involved. This fact has forced the companies to think new business strategies in order to survive in this red ocean where offer is higher than demand and client is expecting higher quality standards of service. Moreover, the expectations of the clients have evolved in the last years due to the impact of technology and the globalization among other factors. Because of quality service is defined as the satisfaction of the customer needs according to their expectations, the development of the hospitality skills is crucial for achieving this goal.

Hospitality can be defined as a reflective and interpretative exercise of interrelated concepts such as the journey, the experience, as well as the role of the visitor and the host (Sagadin 2013). Hospitality managers receives the guest to satisfy their needs for food and shelter based on a commercial transaction and conforms to the approach in which tourist hospitality is located. Therefore, understanding what it is and how to develop it is 
key to the training of new professionals (Vázquez Gómez and Osorio García, 2016). Competitive markets and changes in customer behaviour on customers have further transformed the way in which customer interactions are managed (Reilly 2018). At this time, the COVID-19 pandemic poses a major and evolving challenge to the global community and the tourism sector. Tourism is currently one of the most affected sectors and this fact forces companies in rethink how to offer a unique, different and better service than their competitors. Thus, the concept of Hospitality will play a leading role and it is important to include the development of these skills in the training of the professionals.

The article has a dual purpose. On the one hand, this paper proposes the development of service orientation, empathy and teamwork as some of the key competences in order to achieve an excellent service aligned with the client expectations and hospitality skills. On the other hand, the research presents an experimental learning framework to promote the development on those competences within Tourism and Hotel Management studies. This experiential framework is organized in three phases during the development of the academic studies. The discovery phase is focused on identifying the initial level of the hospitality skills. Next, the reflection phase drives students to reflect about the application of these competences. Finally, the experience phase gives to the students the chance of training these skills in real situations. Therefore, this framework provides to the academic supervisors the opportunity of monitoring the development of these skills through the different academic years in order to contribute to the professional development of the students.

The article is structured as follows. Chapter 2 reviews key competences linked to hospitality, defines concepts such as quality of service, new customer expectations and hospitality from different points of view. Moreover, reflects the development of key competences in Tourism and Hospitality studies, chapter 3 presents a learning framework for the development of these competences and chapter 4 sets out the conclusions and future lines.

\section{Key competences linked to hospitality}

Quality of service and the evolution of the customer expectations are two key elements to understand how to satisfy the expectations of the client. This section reviews the concept of quality service and the evolution of the customer expectations in order to better understand their impact in the hospitality sector and, based on that, identify some key competencies related to offer an excellent service.

\subsection{Quality of Service}

Quality of service is defined as the customer's overall judgment of the excellence or superiority of the service, which results from a comparison between consumers' expectations, what they believe service companies should offer, and their perceptions of the outcome of the service offered. This is a dynamic approach in that expectations may differ depending on the customers and the time the service is provided (Cueva-Trelles 2015). Quality of service is a concept that revolves around the needs of the customer. For example, in some types of establishments the customer expects to receive unique services each time as these are the essence of the strategic positioning of that brand and offer added value (Porter 2008).

The measurement and analysis of the perceived quality of the service from the perspective of external customer satisfaction is a basic element, without doubt, in order to understand the customer and by extension the market in which the company operates, it is necessary to listen to the customers, to know what their needs are, and to capture and study data on their level of satisfaction. Due to the advantages that this represents for the selected hotel chain, the application of a procedure to carry out the analysis and measurement of the quality of the service to the external customer in the hotels that make up the chain has been established as a field of action (González Arias, Frías-Jiménez and Gómez-Figueroa 2016). There are different methods for measuring the quality of service, with two schools standing out. (Duque 2005) On the one hand, the Nordic school defined the image model by relating quality to corporate image, stating that the way consumers perceive the company is the company's corporate image. It is the perception of the technical and functional quality of the services provided by an organization and has an effect on the overall perception of the service. On the other hand, the American school created the ServQual Model as an instrument to quantify the quality of service based on the evaluation of the expectations and perceptions of a customer (Duque 2005). Of these two approaches, ServQual has been widely applied in the hospitality sector effectively in airlines, hotels, restaurants (Santomà and Costa 2006) and is a reference model for international hotel chains such as Ritz Carlton.

The ServQual model proposes contrasting customer expectations with the acquisition of a service and the perception once it has been received. The ServQual measures the quality of service as a mismatch between the expectations prior to consumption of the service and the perception of the service provided, and the latter can be measured from the difference between the two concepts. The greater the difference between service perception and expectations, the lower the quality. As shown in figure 1, the general mismatch (Gap 5) can be the result of four mismatches (Gap 1, Gap 2, Gap 3, Gap 4) (Parasuraman, Zeithaml and Berry 1988). 


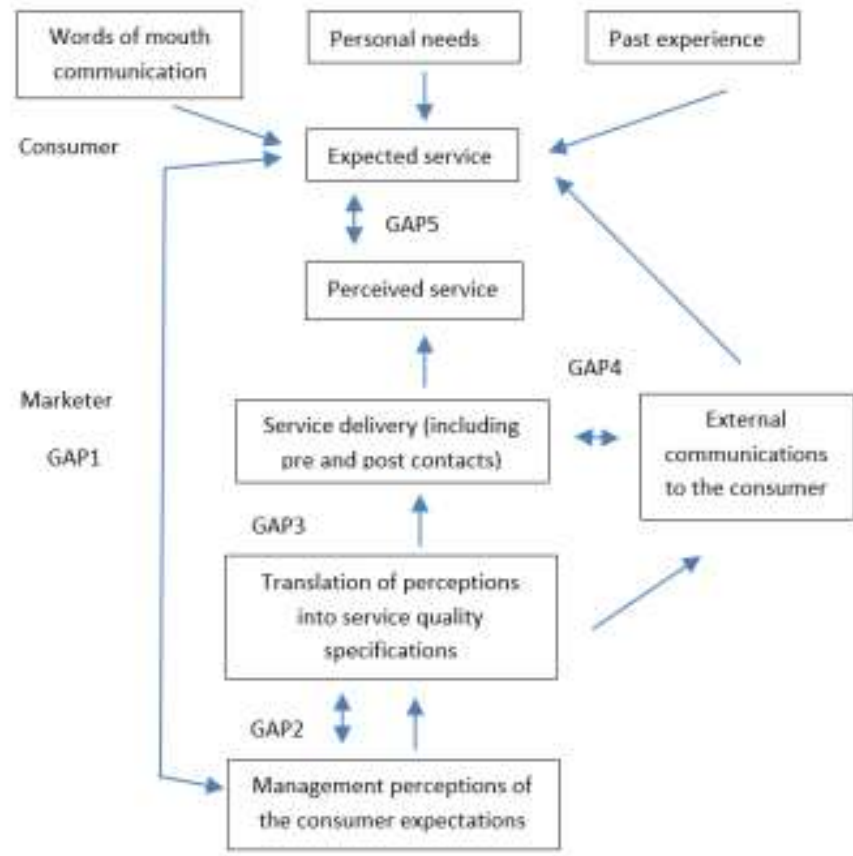

Figure (1): The ServQual model measures the difference between the service received and the customer's expectation in which 5 actionable gaps are identified

The SERVQUAL scale has a greater informative contribution than other methods of measuring quality, makes it possible to determine the most relevant attributes for clients in relation to their expectations, allows the identification of strong and weak points in the provision of services and contributes positively to the improvement of the decision-making process (Anjos and França 2009).

Customer satisfaction and loyalty are essential components for increasing the competitiveness of organisations and can only be achieved by identifying their needs and expectations, as well as knowing which quality factors are most relevant to satisfy them (González Arias, Frías-Jiménez and Gómez-Figueroa 2016). The quality of its products and/or services is a fundamental factor for the correct functioning of a business organisation, which leads to the satisfaction of customer needs and expectations (Holgu 2017).

\subsection{New customer expectations}

Customer expectations are understood as consumer needs, which they feel should be delivered by a service provider (Sanchis and Gil Saura 2012). It is important to bear in mind what our clients' expectations are and to design services that are specially aligned with the clients' needs since the same person, for example, may have different needs when travelling for business than when travelling for pleasure with their family (Porter 2008).

In order to offer a valuable service and therefore meet customer expectations, it is important to be clear that market orientation is the set of cross-functional processes and activities, aimed at the creation and satisfaction of the customer through the continuous evaluation of their needs (González-Gallarza Granizo, Gil Saura, \& Arteaga Moreno 2011). In the world of hospitality, the guest is the center of all interaction and their relationship with the host is an intercultural, cognitive and psychological experience (Vázquez Gómez and Osorio García 2016). Competitive markets, changes in customer behaviour and the ability of technology to collect customer information have further transformed the way in which customer interactions are managed (Reilly 2018).

Service quality understood as meeting customer expectations is a key strategy for framing organizational structure and functionality within parameters that take into account customer expectations and needs, as well as the importance of the human resources the organization needs to respond to these demands. In this effort to aim for satisfied and loyal customers, it is essential to understand what they expect from the products and services they receive. On the basis of this knowledge, it is possible to define improvement projects, operational plans and lines of action in the daily activity of the organization that generate satisfaction, loyalty and, consequently, an increase in profits (González Arias, Frías-Jiménez and Gómez-Figueroa 2016). 


\subsection{The faces of hospitality}

Next, hospitality is approached from the perspective of society, university and company which have key elements as shown in figure 2 .

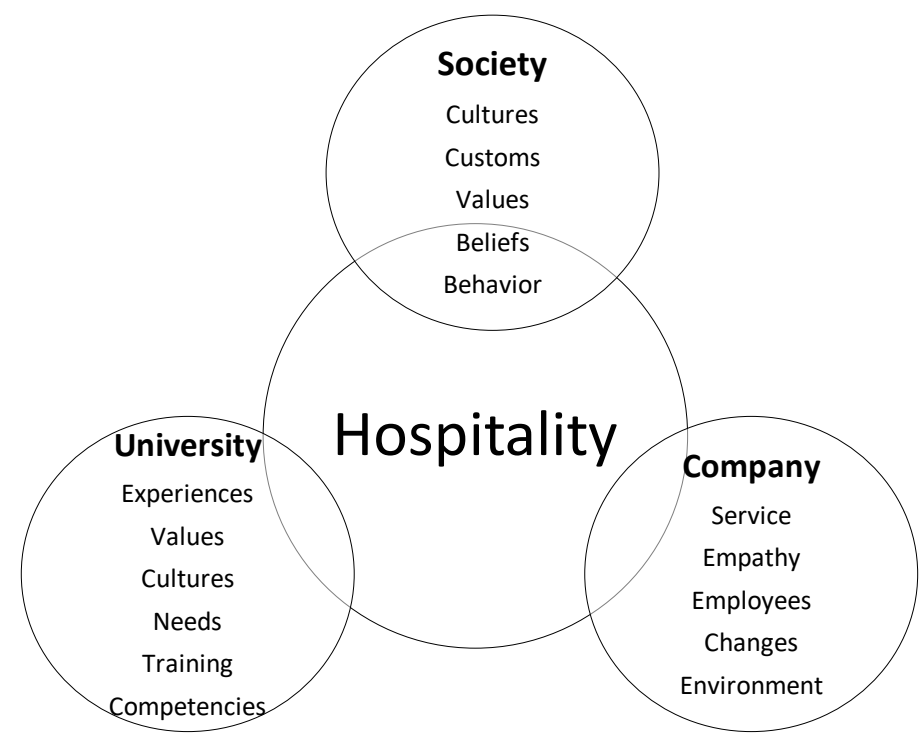

Figure (2): It shows the three faces of hospitality, from the society, the university and the company

\section{Society:}

Society has understood the concept of hospitality in different ways across cultures and eras. When the development of this area began to grow, it was understood as an aspect of capital investment throughout the world (sandro formica 1996). To understand correctly what culture means, it would be interesting to start by defining the concept of culture. This term is understood as a set of basic assumptions and values, life orientations, beliefs, policies, procedures and behavioural conventions that are shared by a group of people and can influence the behaviour of each member (Spencer-Oatey 2009). Culture can be divided into five different dimensions: power distance, avoiding uncertainty, individualism and collectivism, masculinity and femininity, and long-term and short-term orientation (Bolton et al., 2013). The sixth dimension of culture is indulgence in moderation (Hofstede and Hofstede, G.J.Minkov 2010).

Therefore, when relating the above concepts to the hospitality industry, it is important to take into account the place and context in which hospitality and tourism development have begun to understand the concept of hospitality in all cultures.

\section{University:}

There is an emerging horizon of a type of tourist who is more sensitive to new experiences and values, with greater criteria in their decision-making processes, more respectful of local cultures and interested in them, and capable of valuing cultural contents, those that are authentic and rigorously interpreted. This long-term perspective can and must also mean a change in the generation of adequate supply to meet new needs. Faced with these changes in the tourism sector, the university is considering changes in its methodologies in order to adapt to the new needs of the sector. All of this has led to the consolidation of training in tourism and hospitality in the university sphere over the last decade.

There were two first institutions that started to offer hospitality programmes. These were: Ecole Hôtelière de Lausanne (Switzerland) in 1893 and Cornell University (Nueva York; United States). Regardless of the location, the programmes offered by these two institutions had the purpose of preparing students for careers in different areas of hospitality and tourism (sandro formica 1996).

The faculty aims to manage the talent of future professionals by preparing them for their immediate future as talent management is a source of competitive advantage (Reilly 2018). On the other hand, reflections on hospitality in the academic field have highlighted the need to take up again the foundations of hospital action, and bring them to the sphere of institutions providing food and beverage and accommodation services (Vázquez Gómez and Osorio García 2016). Often, hospitality management students studied the common modules together with generic business students, with little application to the details of the hospitality sector (Lashley 2015). 


\section{Company:}

The hospitality industry has evolved dramatically due to the global economic transformation and the phenomenon of globalization, and with it, the way it designs, develops and improves its products and services. The sector has its particular characteristics, which are the intangibility of the services through experiences, inseparability of the product and consumption of the specified service, as well as its heterogeneity of services among others. However, going further and deeper, this industry is particularly different from other sectors, as it is considered a human resource-centered industry. The success of any tourism enterprise depends on carefully considering everything outside of it and within it. The importance of looking at the environment is given by its constant changes according to the dynamics of tourism as an economic activity and its evolution, as well as by those elements that the company possesses which are considered to be strong points, which can be strengthened, and which allow it to face up to the situation projected by the environment (Ruíz Torres and Herrera Consuegra 2012).

There is a set of intangible assets that must be managed, not only to maintain, but especially to strengthen the competitiveness of enterprises. Thus, intellectual capital can be defined as a set of assets of a company which, although not reflected in traditional accounting statements, generate value in the future as a result of aspects related to human capital and other structural aspects such as: the capacity for innovation, customer relations, the quality of processes, products and services, cultural and communicational capital. All this allows a company to take better advantage of opportunities than others, giving rise to the generation of future profits (Gazzera and Martínez 2009).

It is crucial to understand that not only the Human Resources Department in an organization can do all the work if it is not backed up by the leader's actions and ways of doing things. There has been a general misconception in the recruitment of managers, supervisors and directors who do not understand that dealing with human resources is one of their main duties and is part of their role in continuing to motivate their respective teams. Another important point is training, in which companies invest large amounts of money but do not get the expected results, so leaders are frustrated because they do not know how to improve their team's performance. When intangible services are provided, an important role appears in the performance of employees, defined by their personality, attitude, appearance and behaviour, which indirectly projects the image of the organization and will subsequently affect the overall customer experience (Bharwani and Butt 2012). This important function of employee hospitality makes the industry highly dependent on them when trying to provide excellent service and, at the same time, be a profitable business. That is why Human Resource specialists have a challenge, so they have the role of making these employees happy and motivated to have the lowest possible turnover (Myung et al. 2013). Hotel companies today are aware that to stay in the market they must make radical changes in their quality of service, not only towards their external clients, but also towards their collaborators, the services offered are historically perceived by both the tourist and the receptionist, with a different experience during the accommodation process (Veloz 2016).

\subsection{Key hospitality competencies}

Boyatzis coined the term competence as an underlying characteristic of a person that drives or causes superior or effective performance (Boyatzis 2002). Competency-based education focuses on individual needs, learning styles and potential for the student to master the skills identified by the industry. It formulates cognitive activities within certain frameworks that respond to certain established indicators and states that they must remain open to the future and the unexpected. In this way, it is possible to say that a competence in education is a convergence of social and affective behaviours and cognitive, psychological, sensory and motor skills that allow a role, performance, activity or task to be carried out adequately. The concept of competence, as it is understood in education, results from the new theories of cognition and basically means knowledge of execution. Since every process of "knowing" is translated into "knowledge", it is possible to say that competence and knowledge are reciprocal: knowing how to think, knowing how to perform, knowing how to interpret, knowing how to act in different scenarios, from oneself and for others (Vázquez 2015).

Service companies emphasize the importance of developing various skills and the training of competencies such as teamwork and service orientation among others. Investment in training and skills development programmes is significantly associated with the ability to provide a quality service. Therefore, it is important to develop the competence of service orientation as its adoption by service companies has become in recent years a crucial factor in improving customer satisfaction, customer loyalty and employee satisfaction and therefore company profits (Zehrer 2009). It is important to develop an awareness of these operational needs in order to develop a greater awareness of hospitality (Lashley 2015).

Tourism makes contact between cultures more dynamic as the journey itself involves not only a movement in space, but also contact with an "Other". Some authors define travel as an intercultural encounter that builds bridges between two different cultures, through coexistence and communication. This proposes to problematize, how the experiences of the tourist are in the place of the "Other", in terms of the "own" and the "other". (Noguero 
2013). The basic purpose of hospitality is to establish human relationships or strengthen existing ones (Vázquez Gómez and Osorio García 2016). This reflection invites us to consider the importance of empathy as another of the necessary skills to be developed in hospitality professionals, since empathy has an influence on creating a better understanding in the tourist-hospitality interaction, by allowing them to understand and see relationships from different points of view (Fox 2015). Empathy, understanding the needs of customers, affects whether a customer recommends a hotel or a restaurant and the subsequent intention to return to these establishments (Gracia and Gumbau 2008).

Finally, this desire to provide an "experience" for consumers also requires promoting the relationship between employees (Clayton and Boxill 2012). Practices that emphasize empowerment and teamwork are seen as a combination of developing a service culture and harmonising the relationship between employer, employees and customers (Zheng 2009). Teamwork is vital to an organization because it improves performance, particularly when problems are complex and multi-faceted. Therefore, teamwork is key to developing an excellent customer experience (Özgener 2003).

Therefore, the skills of service orientation, empathy and teamwork respond to the need to offer hospitality based on excellence, because hospitality is about interpersonal interactions that go beyond economic transactions, involving psychological, social and cultural aspects (Vázquez Gómez and Osorio García 2016). The competencies highlighted in the previous section are analyzed in more detail below.

\section{Service orientation:}

Service orientation is the ability to customize, trying to smooth the roughness of standardization and this allows to make a difference in the service offered to the customer. The service providers propose aspects that go from smiling at the client; having visual contact with him, and giving him a warm greeting; meeting his needs and tastes; to, spending time with him; offering him help; having a brief conversation, or showing personal interest in his needs (Vázquez 2014). In my professional experience, I usually collaborate in the organisation of training in hotel companies for their employees and one of the key points is always customer orientation, emphasising the importance of kindness, smiles, and close treatment since, although it seems obvious, this does not always happen in professionals.

The emotional intelligence and service orientation are two key features considered relevant in students in the tourism industry, both of which have a direct impact on the final service offered to the client. A person with high service-orientation skills possesses the following characteristics: positive attitude and cheerfulness, enjoys working with and for other people, has the ability to put the client at the centre of everything, has a high level of energy, considers work primarily as a human relations profession, is flexible and enjoys receiving new demands and experiences, and finally, allows clients to be right, even if they are not (Walsh, Chang and Tse 2015).

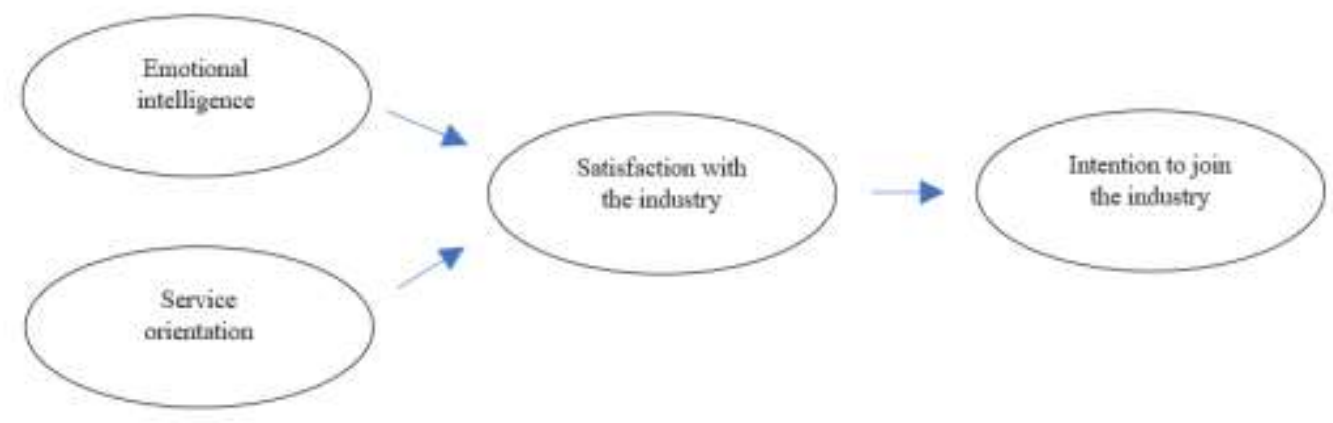

Figure (3): Key features of students who want to study Tourism

It is important to develop and instil leadership styles focused on service orientation to generate customer loyalty, especially in-service sector organisations. The development of this competence can be included in Leadership Development Programmes (Popli and Irfan 2017).

The automation of service processes and a changing balance of co-production of employee services to customers is becoming the norm in many industries, creating a more commoditized and digitized economy. However, this movement is far from human touch, which is particularly evident in the field of hospitality where human contact skills are seen as a source of competitive advantage contributing to the efficiency of service delivery (Solnet et al. 2019). New customers are connected customers, who wish to have multiple possibilities to interact with the company during the whole process of purchase or enjoyment of the service and expect to receive an excellent service before, during and after that process (Mosquera, Olarte Pascual and Juaneda Ayensa 2017).

Service orientation refers to a collection of individual predispositions and an inclination to provide service, to be courteous and helpful, thoughtful and cooperative in dealing with customers. There are different personal 
factors and contextual influences that impact the final customer experience (Ross, May and Stuart 2020). Customer orientation is key to obtaining customer satisfaction. Satisfaction leads to loyalty. Once customers have placed their trust in a company and are confident that the company will continue to deliver high quality products, they will continue to use its services (Wan Nur Syifa Wan Ahmad Tajuddin and Syafiqah Md Nayan 2020).

\section{Empathy:}

Empathy is the cognitive and affective recognition of one person's state of mind by another. It involves deep understanding, intellectually and emotionally, of the other's life situation. Although there are authors who give more importance to cognitive aspects and others to emotional aspects, in general, the relevance of both aspects is recognised (Martínez, V. Perez 2011). The first was cognitive empathy and is described as the ability to understand how a person feels and what they might be thinking. This type of empathy is what helps us to be better communicators by helping and transmitting information in the best way to the other person. It relates to recognising the real state of others by thinking from their perspective and responding accordingly and helps an individual to understand another person's point of view, to anticipate the reactions and needs or opinions of others. Emotional empathy is the ability to share another person's feelings (Goleman 2014).

One of the most important aspects of thinking about a design created from empathy is to interact directly with the user of the service being designed. Without their active participation, it is difficult, if not impossible, to reach a level of empathy that has a positive influence on the overall design (Fox 2015).

The competence of empathy has been considered an important factor in understanding and meeting the needs of customers and is considered one of the five main requirements needed to provide a high quality service; it is openness to the other and the others, it is being accessible to the requirements of the world, attentive to what is different from oneself (Gabriel Porta and Nelida Flores 2017).

Empathy is the ability to understand and identify with the thoughts or feelings of another as if they were one's own. To feel and show empathy, it is not necessary to share the same experiences. It is about understanding the other person's point of view and perspective (Barison 2018).

Since the tourism industry is evolving due to the effects of globalisation and the innovation of products and services offered, empathy should be recognised as one of the skills that a professional in the tourism sector should acquire and develop in higher education institutions. The competence of empathy allows the work of the educational world to be intertwined with the working environment. This is due to the fact that the labour market requires agents of change, which is why universities must train flexible, empathetic and entrepreneurial graduates (Rivas García, Cardoso Espinosa and Cortés Ruiz 2019).

\section{Teamwork:}

The globalisation of the economy has created a new context, which shows that the competitiveness of organisations is based on skills. A new awareness is thus generated, with competence management being a key factor for success, as well as an essential and inevitable strategy for the survival of organizations. In order to be able to adapt in this changing world, the universities, as institutions responsible for the preparation of professionals and their professionalisation, have to respond to the needs of the moment and, therefore, cannot be separated from the relationship between the academic world and the world of work. Transversal competences are now treated like any other competence. In other words, university students face learning processes that allow them to work, learn and evaluate their teamwork, negotiation and decision-making skills. (Nadal 2015).

Teamwork is essential in hospitality. A hospitality organisation is made up of different departments and working groups that must work together and in coordination to meet and exceed the needs of the guest and also to achieve the main objectives of the company. Generally, the terms team and group are used synonymously, but they are not the same. Learning to work in teams has been considered one of the most important interpersonal skills a person can develop to obtain a job, be productive and achieve professional goals and successes. Teamwork skills are the most important requests from recruiters in the hospitality industry. They are often deficient in college graduates and, at the same time, are among the top ten skills that employers consider good employees should have (Kapoor and De Vill-López 2015).

Teamwork is one of the key competencies for the development of many professionals. That is why this competence must first be defined in the curricula and then controlled and ensured by the students (Jaca García, Viles Diez and Zárraga Rodríguez 2016).

Teamwork is a necessary competence for organisational success and its success is entirely influenced by the effectiveness, knowledge sharing and commitment of the team. A team is defined as a grouping of two or more people who interact in a dynamic, interdependent and adaptive way, in which each member has a specific role and shares responsibility for their results in an organisational environment (Rojas, Jaimes and Valencia 2018).

Teamwork is a highly valued skill in the work context. However, it is recognised as deficient in initial university training. The development of competences in Higher Education students is becoming a priority issue for study in all universities with quality systems in place. In this sense, the quality of the students' competence in 
teamwork is also an aim, as well as the assessment that the teachers make of it (Asún Dieste, Rapún López and Romero Martín 2019).

The continuous advance of information and communication technologies (ICT) has created a demand for training in new skills, called 21st century skills. These are made up of high skill competencies such as higher thinking skills and teamwork skills (Almerich et al.2020).

Service companies emphasize the importance of the development of diverse skills and the training of competencies such as teamwork and service orientation among others, responding to the need to offer hospitality based on excellence, because hospitality is about interpersonal interactions that go beyond economic transactions, involving psychological, social and cultural aspects (Vázquez Gómez and Osorio García 2016).

\subsection{Different training for a differential placement}

Higher education must develop training that, assuming a multidisciplinary perspective, integrates knowledge, procedures, attitudes and values in the context of situations of reflection, self-learning, creativity and divergent thinking. Therefore, it is understood that translating these ideas into educational practice requires, in general, that Higher Education institutions join a transformative process by creating structures and ways of feeling, thinking and acting that generate conducive behaviours.

The labour market demands professionals who have skills that go beyond the contents of the curricula themselves: the so-called key or transversal competences, which implies that the agents involved in the teachinglearning process of the students have to develop teaching methodologies that allow the adequate acquisition of these competences. The teaching methodology has to take into account these new challenges faced by the tourism sector. However, the traditional methods of university teaching, in which the teacher decides the information that the students receive, make them into a mere recipient of information, which has shown that these teaching systems prepare students to pass an exam, but do not enable them to face a real situation.

\section{Learning framework for the development of hospitality skills}

The importance of contributing to the professional development of the student and his or her insertion in the world of work should be stressed. The complex and changing environment that university students, future professionals, will have to face will lead them to demonstrate that during their studies they have acquired a comprehensive training that makes theory and practice perfectly interrelated. That is why the EHEA (European Higher Education Area) in recent years has begun to prioritize that studies are oriented to employability, developing professional skills and training students to develop professional activities (Pérez López and García Manjón 2008).

The research proposes an incremental learning process in which the student carries out different learning activities integrated in an iterative process of 3 phases as described in figure 4. Overall, the process helps the student to identify his or her starting point in terms of the level of acquisition of these competences, then to learn and reflect on how he or she could enhance and implement them and finally apply them in the professional world.

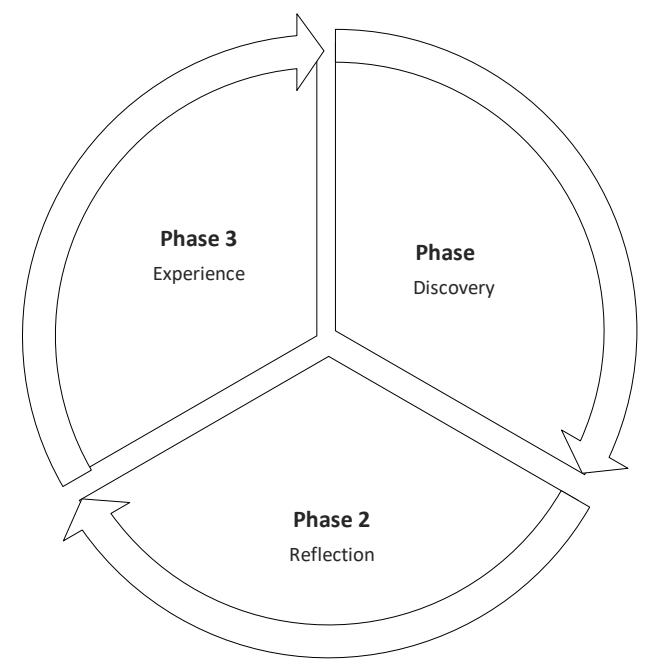

Figure (4): Iterative process for the development of hospitality skills 
Each phase and its deployment are described in more detail below.

\subsection{Planning the phases}

It is recommended that the above phases be deployed during the different academic years. Phase 1 should be deployed at the beginning of the Tourism studies. The student joins the university world and needs to establish a solid learning base. For this reason, the focus of the training is on general training in the field of tourism and hospitality to learn about tourism and its main agents. Phase 2 should be deployed during the Tourism studies. The contents should focus on learning more about the operational aspects linked to the sector and reflecting on them in order to prepare for phase 3 . Phase 3 should be deployed at the end of the course in order to complete the student's preparation for their future professional career. To monitor the progress of the phases it is necessary to define indicators that demonstrate the evolution of the student. It is proposed that these indicators be linked to the competences distributed in the curriculum subjects.

For each competence, a numerical scale from 0 to 4 similar to this one is proposed.

- G06 - Empathy and interpersonal communication: being able to understand other people's emotions and points of view.

Indicators:

0 . Could not be measured.

1. Listen carefully and with genuine interest and express yourself clearly and assertively.

2. Makes an effort to interpret the state of mind of others as expressed in non-verbal expressions, tone of voice, etc... used.

3. He is interested in what motivates others, as well as what they dislike.

4. Is able to give and receive feedback appropriately.

- G07 - Teamwork and collaboration: to be able to cooperate actively and in solidarity to achieve common objectives.

Indicators:

0. Could not be measured.

1. It willingly shares the necessary information available to it to contribute to the different projects.

2. Is respectful of team members with whom he disagrees and places this discrepancy in the situation rather than on a personal level and trusts the integrity, honesty and competence of others.

3. He is willing to negotiate his own objectives or points of view for the benefit of those in the team.

4. Contributes with his or her contributions to the objectives of the organisation.

- G10 - Service orientation: implies the desire to help or serve others.

Indicators:

0 . It could not be measured.

1. Echoes the needs of others.

2. Establishes effective help and support relationships.

3. Identifies the needs of others and is concerned with finding effective ways to resolve them.

4. Identifies the needs of others and anticipates providing tailored solutions.

These indicators are updated for each student at the end of each phase in order to monitor the acquisition of the skills by the student and if necessary, carry out reinforcement sessions to complete the learning.

\subsection{Phase 1: Discovery}

Discovering the student's starting point is key to starting the development process. The aim of the first discovery phase is to assess the state of acquisition of the student's hospitality skills in order to accompany him/her during the process of developing them.

A good way to carry out this phase is through in-depth interviews or tests that help to see the starting point. This practice is usually applied in the selection process of companies. Therefore, it is proposed to carry out interviews or tests that allow the identification and quantification of these competences from a series of structured questions that allow them to be quantified. It is recommended to have different questions for each competence. 


\subsection{Phase 2: Reflection}

The knowledge of how to offer a service allows us to establish an objective towards which we can move forward from the starting point. The aim of phase 2 is to learn and reflect on key concepts in the hospitality industry through the development of the main operational skills linked to the hospitality sector. This reflection allows the students to enhance the competencies to reach the customers' expectations. Some examples of learning activities that are proposed to be used in this phase can be framed in curricular subjects that allow the acquisition of theoretical foundations, such as cases or role plays that pose scenarios with real situations for the students to reflect on the actions to be taken and the consequences that this entails. Other complementary activities to be included to enhance reflection could be interviews or mentoring sessions that help the students to increase their degree of reflection through self-evaluation of why they have acted in a certain way.

\subsection{Phase 3-Experience}

Living real experiences allows for the consolidation of learning. The objective of phase 3 is to contribute to the development of skills linked to the hospitality being studied by living a professional experience that allows the learning and reflection of phase 2 to be put into practice through real situations. The activities proposed encourage learning that is closer to the professional world, such as curricular or extracurricular internships. The Tourism and Hospitality studies are studies with a highly professional approach, which usually include subjects linked to compulsory or optional curricular internships in the degree.

This process can be carried out once or more times within a training programme or between different training programmes, as the need for continuous training has become an indispensable element for a competent professional profile of interest to the sector.

\subsection{Key factors in the progression of learning}

The previous sections have described how to carry out the different phases in order to be able to collect the necessary information to monitor progress in the acquisition of competences. The next step is to analyse the progress of the students and see if there are any factors that can condition the learning progress.

It is proposed to analyse if this progress is the same for all the typology of students, for example, to analyse elements such as maturity, gender, their previous work experience in the sector, if they are aware of the typology of companies in which they are interested to carry out phase 3 among others. Being able to segment the progress of the indicators can give us clues on how to make adjustments in the activities to contribute to more effective learning.

\section{Conclusions and further research}

The hospitality and tourism industry currently play a prominent role in the global economy. The client is increasingly demanding and is characterized by high expectations and greater knowledge of available offers and destinations. Evaluating the concept of hospitality from the point of view of society, the university and companies allows to have a global vision of the concept that helps to understand its importance within our society and sector. While society understands the concept of hospitality from the point of view of empathy with cultures, companies have detected that the management of the concept of hospitality is a differential value with regard to their competitors. Learning how to manage hospitality it is very important in order to face the new expectations of the customer. The current crisis in the sector due to the COVID-19 gives even more importance to these factors.

Taking into account the current and future needs of the sector, universities have the challenge of training the professionals of the future. It is a sector that plays a key role in our society with multiple career opportunities, which means that the sector increasingly requires the entry of new talent with skills that go beyond knowledge. One of the challenges for universities must be the differential placement of students and, therefore, the development of hospitality skills in students is one of the key elements to contribute to their insertion in the labor market. If the future professionals of the hospitality sector develop the key competences, they become competent professionals being able of meeting the new expectations of the client, thus responding to the needs of the sector.

This article has two purposes. On the one hand, service orientation, empathy and teamwork are identified as relevant skills to achieve an excellence service. On the other hand, a learning framework is presented for the development of these competences within the university studies.

- Phase 1-Discovery: The objective is to measure the students 'profile according to the service orientation, empathy and teamwork skills in order to guide them during the process of their developing. This phase proposes the use of analytical tools used by human resources professionals in this field as learning activities for the students.

- Phase 2-Reflection: The objective of this phase is for the students to learn the fundamentals of how to offer an excellent service and to reflect on how to apply them in different real situations linked to the professional world. In this phase it is proposed to carry out learning activities that allow the acquisition of theoretical 
concepts, such as cases or role plays that create real situations. Thus, the students reflect on the actions to be taken in specific situations. Other complementary activities to be included to enhance reflection could be interviews or mentoring sessions that help the students to increase their degree of reflection through selfevaluation about why they have acted in a certain way.

- Phase 3-Experience: The aim of this phase is for the students to put into practice what they have discovered and reflected on in the previous phases so that they become aware of their way of acting, set themselves challenges and learn to solve real situations. The activities that are best suited to offer learning that is closer to the professional world are those that have to do with being able to exercise professional practice.

This research has two ongoing lines of work. One is the deployment of this learning framework in the Bachelor's degree courses in Tourism and Hospitality Management and the other is the expansion of other relevant key competences.

\section{References:}

[1] Almerich, G. et al. (2020). "Structure of 21st century competences in students in the sphere of education. influential personal factors", Educacion XX1, 23(1): 45-74, doi: 10.5944/educxx1.23853

[2] Anjos, G. D. J. \& França, A. A. (2009). "La medición de la calidad de servicio: Una aplicación en empresas hoteleras", Revista Europea de Direccion y Economia de la Empresa, 18(2): 175-186.

[3] Asún Dieste, S., Rapún López, M. \& Romero Martín, M. R. (2019). "Percepciones de Estudiantes Universitarios sobre una Evaluación Formativa en el Trabajo en Equipo", Revista Iberoamericana de Evaluación Educativa, 12(1): 175-192, doi: 10.15366/riee2019.12.1.010

[4] Barison, J. (2018). "There are actually 3 types of Empathy". Here's how they differ and how you can develop them all.

[5] Bharwani, S. \& Butt, N. (2012). "Challenges for the global hospitality industry: an HR perspective", Worldwide Hospitality and Tourism Themes, 4(2): 150-162, doi: 10.1108/17554211211217325

[6] Bolton, R. et al. (2013). "Understanding Generation $Y$ and their use of social media: a review and research Understanding Generation Y and their use of social media: a review and research agenda", Journal of Service Management Marketing Intelligence \&amp; Planning Gautam Parasnis Strategy \&amp; Leadership Iss Cathy Bakewell International Journal of Retail \&amp Distribution Management, 24(2): 328-344, doi: 10.1108/09564231311326987

[7] Boyatzis, R. E. (2002). "El desarrollo de competencias sin valores es como", Journal os Work and Organizational Psychology, 18(2-3): 247-258.

[8] Clayton, A. \& Boxill, I. (2012). "Worldwide Hospitality and Tourism Themes", Tourism Themes Iss, 4(4): 98-100. doi: 10.1108/WHATT-09-2016-0046

[9] Cueva-Trelles, V. (2015). "Evaluación de la calidad percibida por los clientes del hotel Los Portales a través del análisis de sus expectativas y percepciones", $\quad$ p. $80 . \quad$ Available at: https://pirhua.udep.edu.pe/bitstream/handle/11042/2274/ING_552.pdf?sequence=1.

[10] Duque, E. (2005). "Revisión del concepto de calidad del Servicio y sus modelos de medición *", Revista de Ciencias Administrativas y Sociales, 15(25): 64-80.

[11] Fox, R. (2015). "Service empathy", OCLC Systems \& Services: International digital library perspectives, 31(2): 54-58, doi: 10.1108/OCLC-02-2015-0001

[12] Gabriel Porta, L. \& Nelida Flores, G. (2017). "La hospitalidad en profesores memorables universitarios", Revista de Estudios y Experiencias en Educación, 16(30): 15-31. doi: 10.21703/rexe.20173015311

[13] Gazzera, M. \& Martínez, E. (2009). "El valor de los intangibles en las empresas prestadoras de servicios turísticos. Caso hotelería en Toluca, México", Gestión Turística, (Edición Especial), pp. 9-26.

[14] Goleman, D. (2014). "The Brain and Emotional Intelligence: New Insights". 2014th edn. Edited by T. Coalter. Missouri: Regional Business Review. Available at: https://www.nwmissouri.edu/.

[15] González-Gallarza Granizo, M., Gil Saura, I. \& Arteaga Moreno, F. J. (2011). "El valor entregado, la cultura de servicio y la orientación al cliente en los hoteles de España", Papers de Turisme, pp. 7-23.

[16] González Arias, M., Frías-Jiménez, R. A. \& Gómez-Figueroa, O. (2016). "Análisis de la calidad percibida por el cliente en la actividad hotelera", Organización del trabajo y de la producción, XXXVII(3), pp. 253-265. Available at: http://scielo.sld.cu/pdf/rii/v37n3/rii040316.pdf.

[17] Gracia, E. \& Gumbau, R. M. G. (2008). "Estudio de la calidad de servicio como base fundamental para establecer la lealtad del cliente en establecimientos turísticos", Fòrum de Recerca, (13): 178-187.

[18] Hofstede, G. \& Hofstede, G.J.Minkov, M. (2010). Cultures and Organizations: Software of the mind. 3a. Franco Angeli.

[19] Holgu, C. (2017). "Ciencias Holguín, Revista trimestral, Vol. 23, No.3, julio - septiembre, 2017", 23(3): 1-13. 
[20] Jaca García, M., Viles Diez, E. \& Zárraga Rodríguez, M. (2016). "Desarrollo de la competencia de trabajo en equipo en un grado universitario", Memoria Investigaciones en Ingeniería, 14(14): 23-34.

[21] Kapoor, S. \& De Vill-López, B. (2015). "Developing teamwork skills in hospitality management college students", Tourism Research Institute, 10(1): 10-24.

[22] Lashley, C. (2015). "Hospitality studies: escaping the tyranny?", Quality Assurance in Education, 23(4):364-377. doi: 10.1108/QAE-04-2015-0014

[23] Martínez, V. Perez, O. (2011). "La empatía en la educación : estudio de una muestra", Psicologia Iztacala, 14(4): 174-190.

[24] Mosquera, A., Olarte Pascual, C. \& Juaneda Ayensa, E. (2017), "Understanding the customer experience in the age of omnichannel shopping", Revista ICONO14 Revista científica de Comunicación y Tecnologías emergentes, 15(2): 92-114. doi: 10.7195/ri14.v15i2.1070

[25] Myung, Y. et al. (2013). "Expert recommendation system based on analyzing expertise and networks of human resources in National Science \& Technology Information Service", Journal of Central South University, 20(8): 2212-2218, https://doi.org/10.1007/s11771-013-1726-1

[26] Nadal, C. T. (2015), "La evaluación de la competencia trabajo en equipo de los estudiantes universitarios", Revista d’Innovació Docent Universitària, 8(8): 86-97, doi: 10.1344/ridu2016.8.10

[27] Noguero, T. (2013). "La hospitalidad como condición necesaria para el desarrollo local 1", Revista Hospitalidade, X(2): $161-212$.

[28] Özgener, Z. evk. (2003). "Quality function deployment: A teamwork approach", Total Quality Management and Business Excellence, 14(9): 969-979, doi: 10.1080/1478336032000090897

[29] Parasuraman, A., Zeithaml, V. \& Berry, L. (1988), "SERVQUAL: a multiple-item scale for measuring consumer perceptions of service quality", Journal of retailing, 64(1): 12-40.

[30] Pérez López, M. C. \& García Manjón, J. V. (2008), "Espacio Europeo de Educación Superior , competencias profesionales y empleabilidad", Revista Iberoamericana de Educación, 46(9): 1-12. Available at: empleabilidad; competencia.

[31] Popli, S. \& Irfan, A. (2017). "Leadership style and service orientation: the catalytic role of employee engagement", Journal of Service Theory and Practice, 27(1): 292-310, https://doi.org/10.1108/jstp-07-2015-0151

[32] Porter, M. E. (2008). "¿ Qué es la estrategia ?" Harvard Business Review América Latina, pp. 1-21.

[33] Reilly, P. (2018). "Building customer centricity in the hospitality sector: the role of talent management", Worldwide Hospitality and Tourism Themes, 10(1): 42-56. doi: 10.1108/WHATT-10-2017-0068

[34] Rivas García, R. M., Cardoso Espinosa, E. O. \& Cortés Ruiz, J. A. (2019). "Propuesta de las competencias profesionales en turismo desde el enfoque del empleador / Proposal of Professional Competencies in Tourism from the employer's approach", RIDE Revista Iberoamericana para la Investigación y el Desarrollo Educativo, 9(18): 195-214. doi: 10.23913/ride.v9i18.418

[35] Rojas, M., Jaimes, L. \& Valencia, M. (2018). "Efectividad, eficacia y eficiencia en equipos de trabajo", Espacios, 39 (6): 11.

[36] Ross, T., May, A. \& Stuart, A. (2020). "The personal and contextual factors that affect customer experience during rail service failures and the implications for service design", Elsevier, 86: 1-8.

[37] Ruíz Torres, D. R. \& Herrera Consuegra, I. (2012)."La planificación estratégica de los recursos humanos en el centro de las tácticas de desarrollo de la hotelería en Cuba", Revista Caribeña de Ciencias Sociales, (2012-08, August): 17.

[38] Sagadin, T. A. (2013). "Communicating Concepts of Hospitality in Education: Fighting Crisis Through Quality Improvement", 2nd International Scientific Conference Tourism in Soth East Europe 2013, 2, pp. 43-54. Available at: https://ssrn.com/abstract=2289301.

[39] Sanchis, G. \& Gil Saura, I. (2012). "Expectativa satisfacción y lealtad", Papers de Turisme, 37-38, pp. 7-25.

[40] sandro formica (1996). "European hospitality and tourism education: differences with the American model and future trends", Pergamon, 15(4): 317-323, https://doi.org/10.1016/s0278-4319(96)00039-4

[41] Santomà, R. \& Costa, G. (2006). "Calidad de servicio en la industria hotelera: revisión de la literatura", Revista De Análisis Turístico, 0(3): 10. Available at: https://www.aecit.org/jornal/index.php/AECIT/article/view/53/48.

[42] Solnet, D. et al. (2019). "Leveraging human touch in service interactions: lessons from hospitality", Journal of Service Management, 30(3): 392-409. doi: 10.1108/JOSM-12-2018-0380.

[43] Spencer-Oatey, H. (2009). "Culturally Speaking. Culture, Communication and Politeness Theory", The Modern Language Journal, 93(4): 646-648, https://doi.org/10.1111/j.1540-4781.2009.00947.x

[44] Vázquez Gómez, R. A. and Osorio García, M.- (2016). "La hospitalidad en la prestación del servicio turístico. Una revisión sobre sus planteamientos teóricos", International Journal of Hospitality Management, 10: 43-75. 
[45] Vázquez, R. A. (2014). "La hospitalidad en el servicio: de la estandarizacióna la personalización", Hospitalidad ESDAI, 26: 23-37.

[46] Vázquez, Y. A. (2015) "Educación basada en competencias", Revista De Educacion En Jalisco Mexico, pp. 1-15. Available at: http://educacion.jalisco.gob.mx/consulta/educar/19/argudin.html\%5Cnfuente: http://educacion.jalisco.gob.mx/consulta/educar/19/argudin.htm.

[47] Veloz, C. (2016). "Calidad en el servicio de las empresas hoteleras de segunda categoría", Revista Ciencia UNEMI, 9(18): 21. Available at: file:///D:/300-863-1-PB.pdf.

[48] Walsh, K., Chang, S. \& Tse, E. C. Y. (2015). "Understanding Students' Intentions to Join the Hospitality Industry: The Role of Emotional Intelligence, Service Orientation, and Industry Satisfaction", Cornell Hospitality Quarterly, 56(4): 369-382. doi: $10.1177 / 1938965514552475$

[49] Wan Nur Syifa Wan Ahmad Tajuddin \& Syafiqah Md Nayan (2020). "Rising customer satisfaction", Journal of Undergraduate Social Science and Technology, 2(2): 1-5.

[50] Zehrer, A. (2009). "Service experience and service design: concepts and application in tourism SMEs", Managing Service Quality: An International Journal, 19(3): 332-349. doi: 10.1108/09604520910955339

[51] Zheng, C. (2009). "Keeping talents for advancing service firms in Asia", Journal of Service Management, 20(5): 482-502. doi: 10.1108/09564230910995107 